\title{
Final Report on the Great Barrier Reef Expedition.
}

\section{By Dr. C. M. Yonge, Balfour Student in the University of Cambridge.}

$\mathrm{T}$ THE last members of the Expedition left Low Island on July 28,1929 , one year and twelve days after the arrival there of the original party from England. We were so fortunate as to survive the year without serious illness and without damage to the huts, boats, and equipment. The original programme of work was not only completed in almost every particular but also was extended in many ways. It is also gratifying to report that the money raised (less than $£ 9000$ in actual money, though much assistance was received from shipping companies, the Queensland Government,

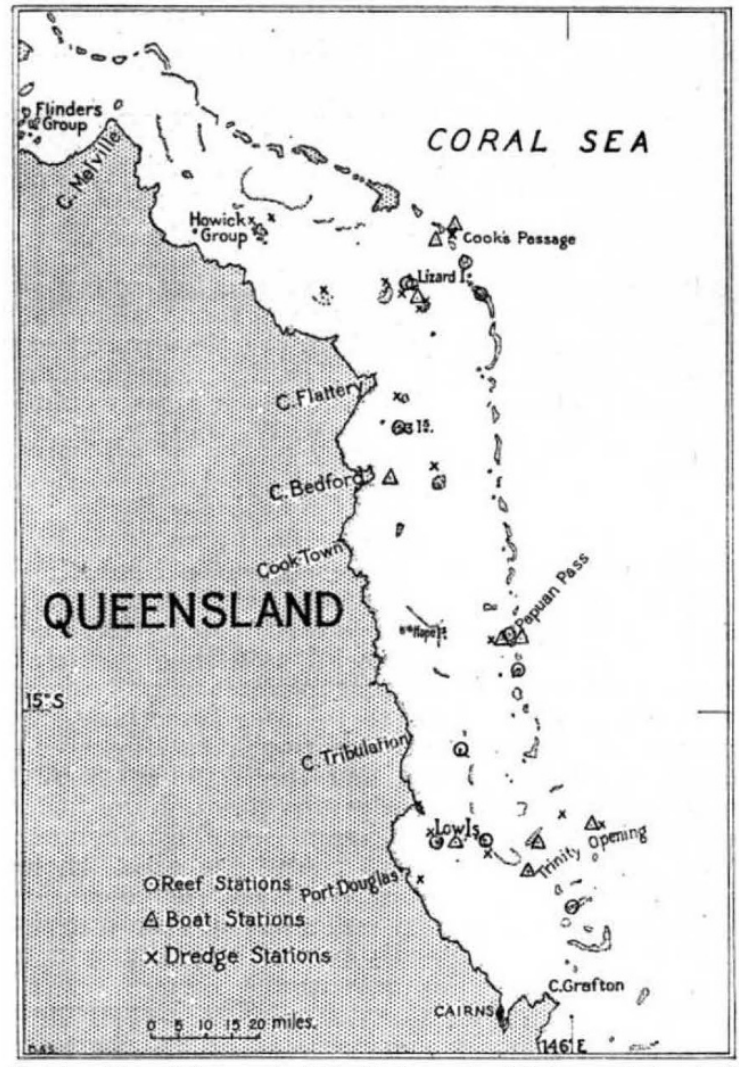

FIG. 1. -Map of the coast of North Queensland between Cairns in the south and the Flinders Group in the north, showing the Great operations of the Expedition.

and scientific sources, representing a considerable additional sum) proved sufficient, but only a very small sum remains for publication, and additional money will be needed for this purpose.

During the second half of the year spent on Low Island, work was extended in many directions up and down the Barrier, when the knowledge gained during the long period of intensive work on the Island enabled the fullest use to be made of comparatively short visits to other regions. Fig. 1, which shows the coast of Queensland from Cairns northward past Cooktown to the Flinders Islands, a stretch of some 200 miles, covers the regions most intensively worked, plankton and hydrographic stations, dredging stations, and reef surveys being all appropriately indicated.

In addition to their weekly station three miles east of Low Island, the boat party worked a series of stations inside and outside the Barrier at intervals between the Island and Cook's Passage. They found no notable differences in the conditions at any of the inside stations from those obtained at the regular station. An upwelling of the deeper water was found close to the Barrier face outside, oxygen saturation being little effected but nutrient salts being brought up from below. There was a notable difference in the forms of plankton taken outside. Mr. Orr, accompanied by Mr. Otter, visited Willis Island, the site of the Commonwealth Meteorological Station and some 240 miles from the coast, on the lighthouse steamer Cape Leeuwin, and took a series of water bottle samples during the voyage. The other work was carried out on the Magneta, a powerful motor launch hired from Townsville.

A series of local dredging stations was also worked with the Magneta and an extended cruise made as far as the Howick Islands. The rectangular dredge and the Agassiz trawl were used, and a varied and interesting collection of the bottom fauna and flora was made. The mud bottom, which is very widespread within the Barrier, is singularly deficient in life of any kind, but the sandy bottom around Lizard Island in particular is covered with a rich growth of Halimeda, on which lives a varied invertebrate fauna providing food for fish which there abound. Wherever there was a big tidal scour, the clean rocky bottom provided a rich, though difficult, dredging ground. Both dredging and trawling were attempted outside Cook's Passage and Papuan Pass in several hundred fathoms of water. Some material was obtained, but without an ocean-going boat equipped with suitable power winches, this type of work cannot be properly conducted. The small motor and friction winch purchased by the Expedition proved invaluable for dredging everywhere and for plankton and water samples in deep water.

The shore party, accompanied by Mr. Spender as surveyor, carried out detailed ecological surveys of Three Isles, an island resembling Low Island in many particulars, and also of portions of the Outer Barrier which was worked from Lizard Island. This latter excursion, carried out on the M.L. Tivoli from Townsville, was undertaken during the new moon spring tides in June, when remarkable day low tides were experienced. These coincided, fortunately, with calm weather, which alone rendered such work on the Outer Barrier possible. During these same low tides the remainder of the party at Low Island visited several of the adjacent reefs on the Luana. Fig. 2 gives some indication 
of the wealth of coral exposed at Pixie Reef, a small coral formation which lies isolated in the middle of Trinity Opening. During the corresponding tides in July, a four-day trip was undertaken with the M.L. Daintree by the majority of the members of the Expedition and portions of the Outer Barrier to the north and south of Papuan Pass examined. The weather on this occasion was far from favourable, but the spectacle of the Pacific rollers breaking on the cemented outer ridge of the Barrier, on to which it was driven by a strong south-easterly gale, was of an impressive grandeur.

A party consisting of Dr. and Mrs. Yonge, Mr. Moorhouse, and Mr. Nicholls left Low Island towards the end of April and spent five weeks in the Torres Straits. The pearling industry at Thursday Island was investigated, also the work of Papuan Industries, Ltd., at Badu Island, and a fortnight was spent on Murray Island, the site of Dr. Mayor's expedition in 1913. The particular object of this trip was a survey, so far as the limited time allowed, of the marine industries in the Straits and an examination of further economic possibilities. The members of the party were especially impressed with the policy of the Queensland Government, which aims at making the Islanders self-supporting; they already run some thirty boats, cutters, and luggers, which collected a considerable proportion of the sixty thousand pounds worth of Trochus shell exported from Thursday Island during 1928. Dense shoals of "sardines" (a small clupeoid) congregate around the shores of Murray Island during the daytime, dispersing at night, presumably for food, for their stomachs are always found empty during the day. They probably come inshore for protection, as they are pursued relentlessly by sharks and other predatory fish. So dense are the shoals and so easy of access, that the natives are able to catch them with

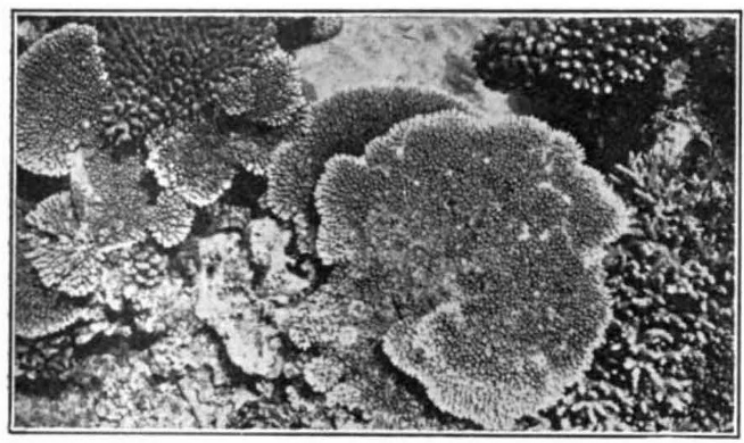

Fic. 2.-Exposed coral, largely species of Acropora, on Pixie Reef, taken during low water springs at the beginning of June.

multipronged spears, as many as six fish being sometimes caught with one throw of the spear. The more usual method of capture, however, is by means of a cast net, and Fig. 3 shows a typical catch. The economic possibilities of this fishery are apparent; the fish are always present, always accessible, and in practically unlimited numbers. Apart from existing fisheries, pearlshell, Trochus, bêche-de-mer, and turtle, there should be great possibilities in the development of a trade in cured fish with the East, while the value of dugong oil is such that a development of this fishery would probably be a sound commercial undertaking. The labour question is greatly simplified by the presence

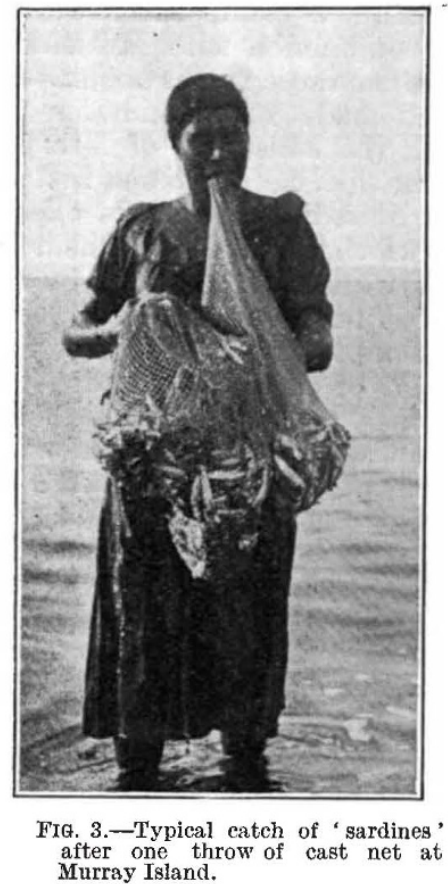

of a highly intelligent and physically almost perfect population on the Islands.

The final excursion took place after the departure from Low Island, Miss Marshall, Mr. Orr, and Dr. and Mrs. Yonge breaking their journey south at Gladstone, whence they visited the Capricorn Islands, a series of isolated coral islands south of the true Barrier. Probably as a result of the more varied character of the winds, these islands differ considerably in character from the northern reefs, while the coral, though less rich in variety, is, if anything, more luxuriant and certainly more spectacular. The economic possibilities are considerable ; there is a turtle-canning factory on Heron Island while fish are abundant, Gladstone possessing the only fish freezing and curing factory in Queensland.

The routine work on phytoplankton and zooplankton from the station three miles east of Low Island and from the lagoon were continued until the end of year by Miss Marshall and Mr. Colman respectively. Only minor fluctuations were found. Mr. Colman also investigated the vertical distribution of the plankton by day and by night, and found that the surface waters by night were five or six times as rich as by day, while the night catches contained many organisms rarely caught by day. Miss Marshall also continued her work on the production of oxygen by the planulæ of Pocillopora and Porites and found that, in the former, the production of oxygen is greatest between 
9 A.M. and 3 P.M., when it just balances the loss due to respiration.

As foreshadowed by the plankton figures, Mr. Orr failed to find any significant changes in the chemical constituents of the sea, in the course of his routine analyses. He continued work on the diurnal changes over the reef flat and in the mangroves, and for a comparison with the latter worked, in conjunction with Mr. Moorhouse and Mr. Nicholls, on those at the mouth of the River Daintree and made an examination of the river itself. With the assistance of Miss Marshall on the biological side, he continued his work on the distribution of sediment and its effect on corals with results which are not in agreement with current views. This work was completed by an examination of the reef flat to a depth of 15 feet by a hand bore. The samples, which will have to be worked out later, were of unexpected interest, Low Island lying apparently on a foundation of soft mud!

The work of the shore party under the direction of Dr. Stephenson has been concerned primarily with the ecology of Low Island and of Three Isles and the region about Lizard Island. The general ecological survey of Low Island, a general account of the physical features of the island and of the faunas associated with the different regions, has been illustrated and extended by the detailed quantitative survey of narrow strips of ground traversing several different zones and by additional surveys of smaller patches. The arrival of Dr. E. Fraser and Dr. S. M. Manton, who both spent some four months on Low Island, alone rendered possible the completion of this extensive programme of work. Dr. Stephenson also had the assistance of Mrs. Stephenson, while Mr. Spender's surveys of the various regions provided the topographical background.

The other work of the shore party included, as previously noted, an investigation of the breeding seasons of selected corals and other animals by the periodic taking of gonad samples over 10 months, and by other means. Special attention was paid to the production of planulæ by Pocillopora and Porites, the development of which was studied in great detail. Dr. Fraser also did interesting work on the development of a species of Eudendrium. The experiment on the growth rate of corals secured on to cement blocks was successfully completed with striking results in many cases. Further data were secured by the marking of corals in situ under water, using the diving helmet. A number of young colonies was collected on clean shells, stones, etc., put out for the purpose. Considerable collections of animals were made during the survey, while Mr. Tandy's botanical collections were supplemented in many ways, notably by the preparation by Miss M. D. Glynne, who stayed with us for three weeks in April, of a map showing the distribution of the Lithothamnion zones.

Mr. Moorhouse confined himself very largely to work of economic importance, although he took every opportunity of assisting Mr. Orr and gaining experience in all branches of the work, experience which will be of great value to him in the future when he will be in charge of work, largely economic in character, for the Government of Queensland. He has spent much time observing the habits and life-history of Trochus, which he found (contrary to previous reports) to discharge its eggs freely into the sea between the months of March and July, the smallest laying animal having a basal diameter of $5 \mathrm{~cm}$. His work on their growth, from measurements of marked animals and monthly measurements of extensive unsorted collections, points to an increase of some $1.7 \mathrm{~cm}$. in basal diameter in 7 months. He is also able to estimate the basal diameter of Trochus one, two, three, and four years old, respectively $2 \cdot 5-3 \mathrm{~cm} ., 4 \cdot 5-5 \mathrm{~cm}$, $7-7 \cdot 5 \mathrm{~cm}$, and $9 \cdot 5-10 \mathrm{~cm}$. This work represents the first accurate information about the breeding and growth of this economically most valuable animal.

Excellent results were obtained with the sponges cut up and planted out, very considerable growth being recorded. Work was continued on the breeding of bêche-de-mer, while all possible information concerning the fish, either at first hand or from fishermen, was obtained. The work done on Murray Island has been noted above.

The leader's party, consisting of Dr. and Mrs. Yonge and Mr. Nicholls, continued their work on the physiology of corals and certain reef animals. The feeding mechanisms of some forty genera of corals were studied; all were found quite capable of capturing animal prey, though the actual mechanism involved showed interesting variations. Further work on the digestive enzymes of corals showed that the amylase previously reported comes from the algæ, not the coral, which, however, contains a weak glycogenase. The powerful protease really consists of two enzymes, an 'erepsin' and a 'trypsin'. Further work was done on the speed of digestion of captured plankton. Waste matter is excreted exclusively by way of the ' absorptive' zone in the mesenterial filaments. Symbiotic algæ have been found degenerating in many places in the tissues, besides the mesenterial filaments, though never in such numbers as in the " absorptive' zone. By heating for an appropriate time at certain temperatures, it is possible to kill many of the algæ without damaging the coral; this occurred naturally on many parts of the reef flat during the low tides in the summer. The algæ intercept the phosphate excreted by the coral, the phosphate content of the surrounding water dropping quickly to zero, but in the case of corals without algæ (for example, Dendrophyllia) the phosphate content quickly rises many hundred per cent.

Further experiments on the oxygen production of the algæ in coral has been carried out, notably experiments with eight corals in jars, samples being taken every three hours over 27-and 12-hour stretches, the results showing that oxygen production only exceeds oxygen consumption during the middle of the day. Similar experiments were conducted at various depths. Owing to the absence of algæ from its tissues, Dendrophyllia was frequently used as a control in these experiments. The effect on certain corals of long deprivation of

No. 3131, VoL. 124] 
oxygen was tested. The experiment involving the feeding and starving of corals in light and darkness was continued, and gave results confirming those recorded in previous statements. Corals kept for four months in a light-tight box on the reef flat showed no ill effects other than those caused by the heavy deposition of sediment which smothered some; the survivors were pale, almost all the algæ being dead, but otherwise healthy. Further evidence has done nothing but confirm the view previously expressed that the algæ are useless as food for the coral, but may be of vital importance as the source of an accessory supply of oxygen.

Less detailed work on the algæ in Tridacna showed that the algæ here are probably of great importance as food. They form the bulk of the contents of the stomach (here modified in structure) and are found in process of digestion in phagocytes and in the digestive diverticula. There is no evidence that they provide any appreciable amount of oxygen, but they may serve to maintain the hydrogen ion concentration in the mantle cavity. The feeding of Tridacna, Pteroceras, and Vermetus was examined in the light of previous work on the feeding of mollusca.

Mr. Nicholls did special work on the calcium metabolism. He was unable to find any evidence of enzyme agency in the formation of the skeleton in corals. He also did further work on the variation in calcium and excess base in coral pools during low tides by day and by night, and on the calcium content of the fluid in the gut and body cavity of Holothurians. A second spawning period for the pearl oyster (Pinctada margaratifera) was found in May, and data as to the rate of growth obtained.

Mr. Spender, who worked for the most part in conjunction with the shore party, completed his detailed survey of Low Island, including soundings outside the anchorage and also at various positions to give characteristic profiles to the reef edge. He also made several level traverses across the flat, along the rampart and over the strips which were being surveyed ecologically. He also surveyed Three Isles, and made general surveys of outer barrier reefs near Lizard Island and around Papuan Pass.

In conclusion, it is particularly gratifying to be able to state that the work of the Expedition, especially on the economic side, will be continued by the Queensland Government, to whom the huts on Low Island and the bulk of the equipment have been given.

\section{The Vegetable Tannins. ${ }^{1}$}

\section{By Prof. K. Freudenberg, University of Heidelberg.}

$\mathrm{T}$ HE subject of the vegetable tannins ${ }^{2}$ is a small field in organic chemistry. Although the subject has been considerably developed and extended in recent years, its beginnings date back to the rise of modern chemistry. One hundred and fifty years ago, Carl Wilhelm Scheele, one of the discoverers of oxygen, in his dark apothecary's shop at Køping in Sweden, allowed an aqueous infusion of Turkish oak galls to be fermented by moulds, doubtless not the first occasion that such a fermentation took place in a pharmaceutical laboratory. But Scheele was one of the best observers chemistry ever had. He noticed that a crystalline substance settled down below the layer of the mould and he was able to recrystallise this substance from water. $\mathrm{He}$ called it sal essentiale gallarum, and it became known in the literature as gallic acid, having the formula<smiles>CCOC(=O)CC(O)O</smiles>

that is, a trioxybenzoic acid.

In Scheele's opinion, the action of the mould on the extract consisted in the removal of impurities, which might prevent the erystallisation of the preformed substance. Some years later, French chemists, however, pointed out that crystalline

1 A lecture given to Section B (Chemistry) of the British Association at Cape Town on July 26, 1929.

2 There is some confusion in the nomenclature owing to the fact that 'tannins' (Gerbstoffe) in general and 'gallotannin' have been termed simply 'tannins' by Emil Fischer.

No. 3131, VoL. 124] gallic acid and the amorphous gallotannic acid are not identical. A Flemish botanist, van Tieghem, made a detailed investigation of the fermentation of gallotannin. In the course of his work he discovered a mould specially suited for the fermentation of gallotannin, namely, the well known Aspergillus Niger. $\mathrm{He}$ was able to show that a mould mycelium, weighing only a few milligrams, was able to decompose some fifty grams of gallotannic acid. He therefore ascribed the action of the mould to an enzyme, named tannase, and further showed that at the same time an alcoholic fermentation sets in, a fact already mentioned by Liebig and attributed to the presence of sugar in the gallotanic acid molecule.

Previously, in 1834, it had been found by Liebig and Pelouze that gallotannin acted upon by dilute acids splits off the same gallic acid obtained earlier by fermentation. In 1850, Strecker published an account of a fundamental investigation on the subject. With hot dilute acid, he obtained in addition to a large amount of gallic acid, a small but definite quantity of glucose.

Unfortunately, at about the same time, theoretical speculations began to obscure clear-cut experimental results. Under the influence of Gerhardt's work on acid anhydrides, Mulder interpreted gallotannin as an anhydride of gallic acid, the sugar content being ascribed to the adventitious presence of an admixed glucoside. Curiously enough, the more analytical methods were improved, the less could Strecker's results concerning glucose be confirmed. His yield of fifteen and more 